\title{
Minerály „ottrélitových“ břidlic u Vápenného Podola v Železných horách (Česká republika)
}

\author{
Minerals of the „ottrélite“ schists from Vápenný Podol in the Železné Hory Mts. \\ (Czech Republic)
}

\author{
Jakub JiRÁsek ${ }^{1)^{*}}$, Dalibor MatÝsek ${ }^{2)}$ a Martin SiveK ${ }^{3)}$ \\ ${ }^{1)}$ Katedra geologie, Př́rodovědecká fakulta, Univerzita Palackého, 17. listopadu 1192/12, 77146 Olomouc; \\ *e-mail: jakub.jirasek@upol.cz \\ 2)Institut čistých technologií těžby a užití energetických surovin \& Katedra geologického inženýrství, \\ Hornicko-geologická fakulta, Vysoká škola báňská - Technická univerzita Ostrava, 17. listopadu 15/2172, \\ 70833 Ostrava-Poruba \\ 3)Centrum ENET, Vysoká škola báňská - Technická univerzita Ostrava, 17. listopadu 15/2172, \\ 70833 Ostrava-Poruba
}

JiRÁSEK J, MATÝSEK D, SiveK M (2020) Minerály „ottrélitových“ břidlic u Vápenného Podola v Železných horách (Česká republika). Bull Mineral Petrolog 28(2): 339-346 ISSN 2570-7337

\begin{abstract}
From the belt of Ordovician metapelites in the Železné hory Mountains, ottrélite was described in 1882. Although the original paper stated the virtual absence of manganese, many papers and books from the $20^{\text {th }}$ century copied just the original name of the mineral, without respect to its chemistry. Since the quantitative analysis was not available, we decided to revise this occurrence. Material newly collected in the vicinity of the Bučina Hill (606 m a.s.I.) SW from the Vápenný Podol village fits the original description, i.e. felsic rocks rich in quartz and illite-muscovite, with significant schistosity and abundant porphyroblasts of dark green mineral of the chloritoid group up to $3 \mathrm{~mm}$ large. Rietveld refinement of powder X-ray diffraction using different input structural models gave the best fit (the lowest $R_{B r a g g}$ ) for the triclinic chloritoid of $P-1$ space group. Unit cell parameters are as follow: $a=5.483(1), b=5.479(1), c=9.1476(5) \AA$, $\alpha=83.452(10)^{\circ}, \beta=76.639(11)^{\circ}, y=59.993(15)^{\circ}$. Its average formula from seven WDS spots is $\left(F e_{0.83} M_{0.17} M_{0.01}\right)_{\Sigma 1.01}$ $\mathrm{Al}_{1.97}\left(\mathrm{SiO}_{4}\right)_{\Sigma 1.02} \mathrm{O}_{0.92}(\mathrm{OH})_{2.00}$, and therefore must be classified as a chloritoid. As accessory minerals in the schist, we found rutile crystals and aggregates, prismatic zircons, a mineral from the chlorite group, and paragonite. Attention was paid to the unexpected occurrence of possibly primary rare grains of xenotime- $(\mathrm{Y})$ up to $10 \mu \mathrm{m}$ with average formula $\left(\mathrm{Y}_{0.71} \mathrm{Sm}_{0.01} \mathrm{Gd}_{0.03} \mathrm{~Tb}_{0.01} \mathrm{Dy}_{0.07} \mathrm{Ho}_{0.01} \mathrm{Er}_{0.05} \mathrm{Tm}_{0.01} \mathrm{Yb}_{0.04} \mathrm{Lu}_{0.01}\right)_{\Sigma 0.96}\left(\mathrm{P}_{1.02} \mathrm{Si}_{0.01}\right)_{\Sigma 1.03} \mathrm{O}_{4.00}$ and more common rhabdophane-(Ce), which forms acicular, partly skeletal crystals in cavities, possibly after leached apatite. Its average formula is $Y_{0.01} \mathrm{La}_{0.18}$ $\left.\mathrm{Ce}_{0.40} \mathrm{Pr}_{0.04} \mathrm{Nd}_{0.15} \mathrm{Sm}_{0.03} \mathrm{Eu}_{0.01} \mathrm{Gd}_{0.04} \mathrm{Al}_{0.02} \mathrm{Ca}_{0.18} \mathrm{Fe}_{0.04} \mathrm{Th}_{0.02}\right)_{\Sigma 1.12}\left(\mathrm{P}_{0.95} \mathrm{Si}_{0.01} \mathrm{~S}_{0.01}\right)_{\Sigma 0.97} \mathrm{O}_{4.00} \cdot 0.97 \mathrm{H}_{2} \mathrm{O}$. We suggest using the term "chloritoid schist" for these metapelites formed at the contact of Middle to Late Ordovician graphite shales with the intrusion of the Variscan biotite granite of the Železné Hory Mts. Plutonic Complex.
\end{abstract}

Key words: chloritoid, rhabdophane-(Ce), xenotime-(Y), Ordovician, Železné Hory Mountains, Czech Republic

Obdrženo 24. 9. 2020; prijiato 7. 11. 2020

\section{Úvod}

Chloritoidová skupina obsahuje monoklinické nebo triklinické nesosilikáty s obecným vzorcem $\mathrm{M}^{2+} \mathrm{Al}_{2}\left(\mathrm{SiO}_{4}\right)$ $\mathrm{O}(\mathrm{OH})_{2}$, kde pozici M obsazuje dvojmocný kationt. $\mathrm{V}$ současnosti jsou známé čtyři platné členy této skupiny: chloritoid s převahou železa na pozici $\mathrm{M}^{2+}$ (Fiedler 1832; Rose 1837), magnesiochloritoid s dominancí hořčíku (Chopin 1983; Chopin a Schreyer 1983) a ottrélit s převahou manganu (Descloizeaux a Damour 1842). Dále se do této skupiny řadí velmi vzácný germaniový analog chloritoidu carboirit, kde germanium nahrazuje křemík v silikátovém aniontu (Johan et al. 1983).

Na našem území byly z této skupiny minerálů zjištěny poměrně běžný chloritoid a výrazně vzácnější ottrélit. Ten byl poprvé popsán ze Železných hor z okolí vrchu Bučina (Krejčí a Helmhacker 1882), a jeho zdejší výskyt se traduje $v$ některých topografických mineralogiích našeho území (např. Kratochvíl 1957; Pauliš 2003). V rámci revize některých manganových fází jsme $v$ roce 2019 ovzorkovali zdejší horniny obsahující „ottrélit" a o výsledcích jejich mineralogické analýzy referujeme.

\section{Lokalizace a stručná historie výzkumů}

Geologicky oblast náleží chrudimskému staršímu paleozoiku středočeské oblasti - bohemika. Studované horniny náleží k vápenopodolské synklinále a tvoří nesouvislý nepravidelný pás mezi obcemi Skoranov a Kraskov na západě a Ptenínem na východě, který je dlouhý asi 5.6 km a široký maximálně 650 m (Holásek et al. 1989). Kontaktně metamorfované fylity a fylitické břidlice se vyskytuji na styku anchimetamorfovaných tmavých jílovitých břidlic a prachovců středního až svrchního ordoviku (míčovské 
souvrství) a variských dvojslídných granitů železnohorského plutonu (Burda et al. 1993).

První popis studovaných hornin pochází z vysvětlivek ke geologické mapě Železných hor (Krejčí a Helmhacker 1882). Ke geologické situaci výskytu břidlic uvádí následující: „Na hranici žuly byly jílovité břidlice zóny $d_{3}$ zcela přeměněny na ottrelitové břidlice, které se vyvíjejí postupným přechodem z černých jílovitých břidlic" a „Zóna

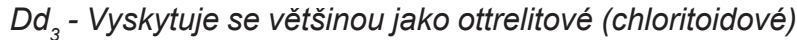
břidlice $v$ nadloží křemencové zóny $d_{2}$ na Bučině, mezi nimi a červenou žulou. $V$ důsledku tohoto uložení a výskytu nad křemencem Ize pás těchto břidlic považovat za analog zóny $d_{3}$. Tyto horniny Ize mimochodem odvodit z metamorfózy zóny $d_{1}$...V bridličnatých světlých porfyrech, na které nasedaji vrstvy zóny $D$ jižním směrem, se nacházejí útržky této břidlice." Detailní petrografický popis z pera Rudolfa Helmhackera ve výše uvedené práci pak uvádí podrobné informace o výskytu břidlicové polohy a zmiňuje, že kontaktní metamorfózu, která přeměnila černé břidlice na ottrélitové, Ize sledovat na povrchu do vzdálenosti mírně nad $1 \mathrm{~km}$ od okraje žulového tělesa. Studované horniny pak popisuje takto: „Ottrelitový fylit vykazuje jasnou břidličnatost procházející světle šedou základni hmotou, ve které jsou uloženy téměř paralelně až 111/4-1 mm široké tmavě zelené tenké destičky chloritoidu (ottrelitu). Obvykle se nachází 40 až 50 takových chloritoidových šupin na $1 \mathrm{~cm}^{3}$, i když u některých odrůd je jejich počet několikanásobně vyšší. "Helmhacker zmiňuje také, že základní hmota horniny je kromě zcela převažujícího jemnozrnného muskovitu tvořena také malým množstvím nahnědlých šupin nejistého biotitu a velmi jemnozrnným magnetitem. Na trhlinách navětrané břidlice objevil limonit. Klíčová pro další text je poznámka pod čarou uvedená na straně 198: „Ottrelit je název odrůdy chloritoidu obsahující významný podíl Mn, což Ize snadno rozpoznat při použití dmuchavky. Náš ottrelit však neobsahuje žádný $M n$, nebo pouze nevýznamné stopy, takže se kryje s odrůdou vénasquitem. Zde se však $v$ textu většinou vedle názvu chloritoid použivá označení ottrelit, $i$ když pokud se používají názvy odrůd, vhodnější by byl termín venasquit (kvưli neprítomnosti Mn). "Takto vstoupil zdejší minerál chloritoidové skupiny do literatury, na kterou odkazují novější práce. Vepřek (1906) tak uvádí zkrácený český překlad výše uvedených mapových vysvětlivek a konkrétně zmiňuje „šupinky chloritoidu neboli ottrelitu“. Hinterlechner a John (1909) pak polemizují $s$ přesným stratigrafickým zařazením ottrelitových břidlic $v$ rámci vrstevního sledu zóny $D$ Želených hor (pozn. spodní silur paralelizovaný s oblastí Barrandienu) a na základě kontaktní metamorfózy břidlic částečně vymezují stáří granitu, který jí způsobil. Detailní rozbor břidlic uvádějí Hinterlechner a John (1910). Publikují tři chemické analýzy této horniny, dva z různých míst západního úbočí vrchu Bučina a poslední z malé jámy jihozápadně

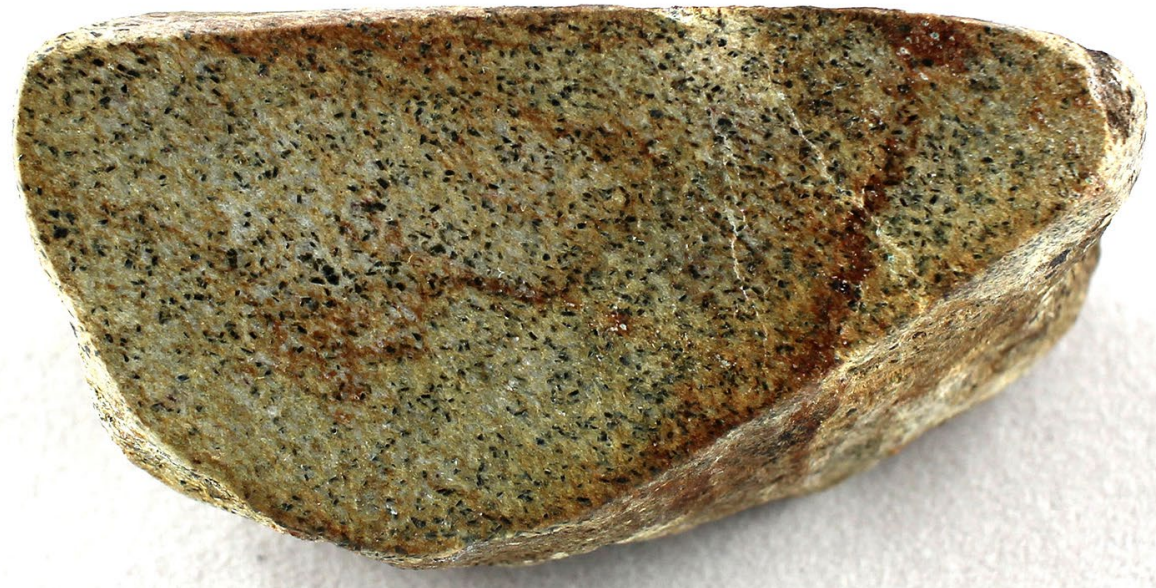

Obr. 1 Leštěná plocha chloritoidové brídlice z jižního úpatí Bučiny s hojnými tmavě zelenými krystaly chloritoidu. Velikost $6.5 \times$ $3 \mathrm{~cm}$. Foto J. Jirásek.
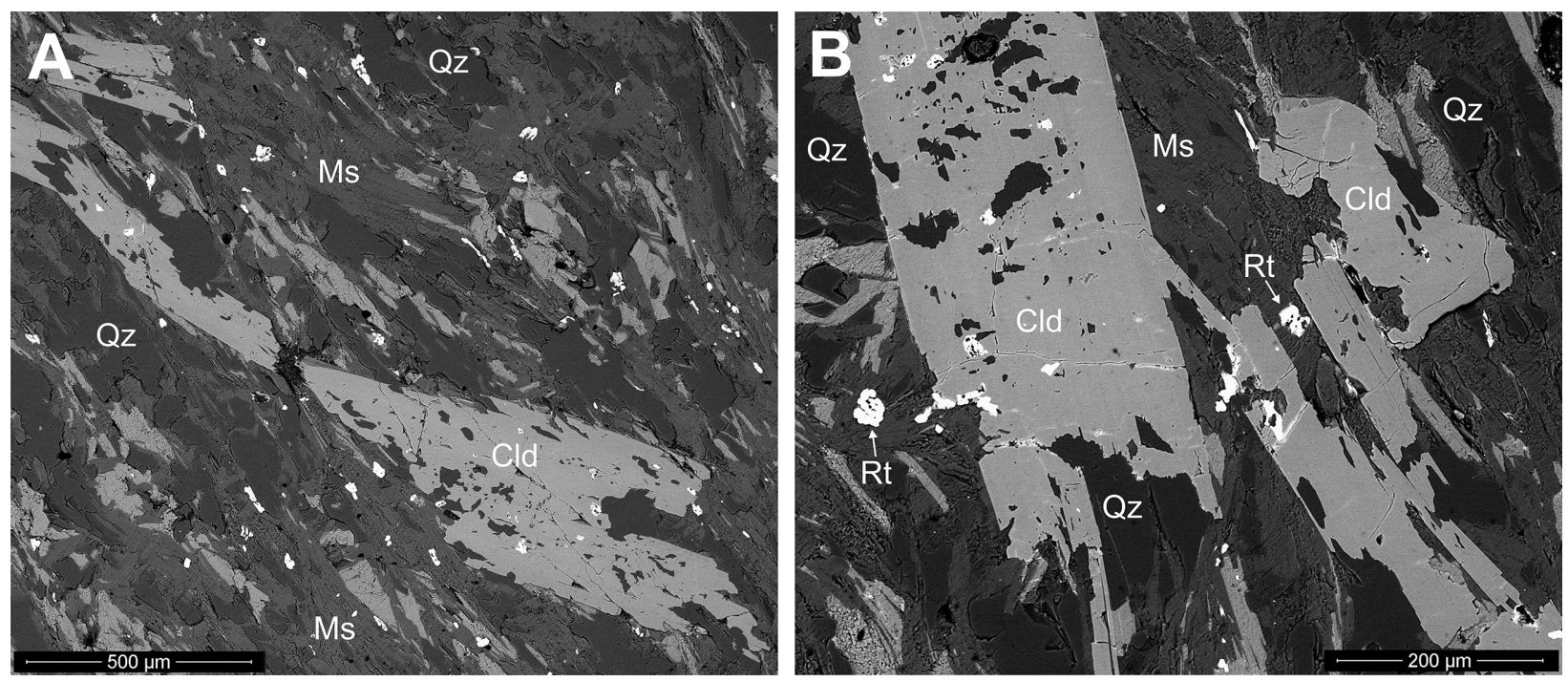

Obr. 2 Nábrusy chloritoidové břidlice zobrazené pomocí zpětně odražených elektronů. Zřejmá je chemická homogenita chloritoidu a velké množství inkluzí zachycených během metamorfního růstu jeho krystalů. Cld: chloritoid, Ms: muskovit, Qz: křemen, Rt: rutil. Foto D. Matýsek. 
od Cítkova. Jako horninotvorné minerály uvádějí křemen, sericit, ottrelit, místy chlorit a kyanit (šedý nebo tmavě zelený, až 1 × 3 mm velký) a nejisté živce, dále místy hojný limonit. Akcesoricky nalezli místy relativně hojný rutil, pigment prítomný pouze $v$ některých vzorcích považují za grafitický.

Zdejší minerál z chloritoidové skupiny pak často v novějších publikacích (např. Slavíková 1939, Kratochvíl 1957), figuruje jako ottrélit (ottrelit). Výjimkou je práce Tučka (1970), který uvádí pod heslem Bučina chloritoid v briidlicích staršího paleozoika. Odkazuje na text přednášky Lázničky z roku 1964, která měla být vydána Národním muzeem a Společností Národního muzea. V uvedeném ročníku se však tento údaj nepodařilo dohledat. Novější topografická mineralogie (Hovorka 1969) uvádí „ve fylitech v oblasti Bučiny jsou známé až $1 \mathrm{~cm}$ velké porfyroblasty chloritoidu“, bohužel bez analýzy nebo odkazu na zdroj této informace. Stejná situace je i u novější práce (Fediuk 1981), která ze zdejší lokality zmiňuje „porfyroblasty šedozeleného chloritoidu se zvýšeným obsahem Mn, zvaného ottrelit...".

\section{Metodika výzkumu}

Sledování morfologie minerálů proběhlo na leštěných nábrusech i prírodních trhlinách za použití autoemisního elektronového mikroskopu FEI Quanta-650 FEG od firmy FEl. Mikrofotografie byly pořízeny pomocí detektoru zpětně odražených elektronů (BSE) v režimu chemického gradientu.

Chemické složení chloritoidu, xenotimu a rabdofánu bylo studováno kvantitativně pomocí elektronového mikroanalyzátoru Cameca SX 100 (Ústav geologických věd, přírodovědecká fakulta MU, Brno, analytik R. Čopjaková) za podmínek: vinově disperzní analýza, napětí $15 \mathrm{keV}$, proud $10 \mathrm{nA}$, průměr svazku elektronů do $6 \mu \mathrm{m}$. Jako standardy byly použity dobře definované homogenní minerály a syntetické fáze: albit ( $\mathrm{Na} \mathrm{K \alpha}$ ), pyrop ( $\mathrm{Mg} \mathrm{K \alpha})$, almandin ( $\mathrm{Si} \mathrm{Ka}, \mathrm{Fe} \mathrm{Ka}$ ), $\mathrm{MgAl}_{2} \mathrm{O}_{4}(\mathrm{Al} \mathrm{Ka}$ ), wollastonit $(\mathrm{Ca} \mathrm{Ka})$, titanit ( $\mathrm{Ti} \mathrm{Ka})$, chromit $(\mathrm{Cr} \mathrm{Ka}), \mathrm{Ni}_{2} \mathrm{SiO}_{4}(\mathrm{Ni} \mathrm{Ka})$, vanadinit $(\mathrm{Cl} \mathrm{Ka}, \mathrm{V} \mathrm{Ka}, \mathrm{Pb} \mathrm{Ma})$, gahnit $(\mathrm{Zn} \mathrm{Ka})$, ortoklas $(\mathrm{K} \mathrm{K \alpha})$, topaz $(\mathrm{F} \mathrm{K \alpha})$, spessartin $(\mathrm{Mn} \mathrm{K \alpha}), \mathrm{SrSO}_{4}(\mathrm{Sr} \mathrm{L \alpha})$, baryt (Ba La), $\mathrm{ScVO}_{4}(\mathrm{Sc} K \alpha)$, lammerit (As La), YAG (Y $\mathrm{L} \alpha), \mathrm{U}\left(\mathrm{U} \mathrm{M} \beta\right.$ ) a $\mathrm{ThO}_{2}$ (Th Ma). U REE byly jako standardy použity syntetické bezvodé fosfáty daných prvků a linie La (La, Ce, Sm, Eu, Gd, Tb, Dy, Er, Tm, Yb), L $\beta$ (Pr, Nd, Ho) a $M \beta$ (Lu). Empirický vzorec chloritoidu byl přepočten na 6 aniontů (kyslík + chlór + fluor), vzorce xenotimu a rabdofánu na 4 atomy kyslíku. Množství vody u rabdofánu bylo dopočteno na základě poměru obsazení strukturní pozice / $\mathrm{H}_{2} \mathrm{O}$ v ideálním vzorci minerálu.

Pomocí práškové rentgenové difrakční analýzy bylo sledováno celkové složení horniny a na magnetickém koncentrátu byly ověřeny i difrakční charakteristiky př́tomného chloritoidu. Měření probíhalo na přístroji Bruker-AXS D8 Advance (Katedra geologického inženýrství VŠB - TU Ostrava), pracujícího s $2 \theta / \theta$ reflexní geometrií měření a $s$ polovodičovým silicon strip detektorem LynxEye za podmínek: záření CuKa/Ni filtr, napětí $40 \mathrm{kV}$, proud $40 \mathrm{~mA}$, krokový režim s krokem $0.014^{\circ} 2 \theta$ a s celkovým časem na kroku $5 \mathrm{~s}$. Mřížkové parametry chloritoidu byly vypočteny Rietveldovou metodou pomocí programu Bruker AXS Topas verze 5.

Magnetický koncentrát byl připraven pomocí permanentního NdFeB magnetu z granulometrické frakce 0.25 $-0.5 \mathrm{~mm}$.

\section{Výsledky}

Minerál ze skupiny chloritoidu vytváří ve studovaných horninách hojné, nedokonale omezené tabulkovité krystaly tmavě zelené barvy o velikosti do $3 \mathrm{~mm}$ (obr. 1, 2). $\checkmark$ některých vzorcích jsou rozptýleny náhodně $v$ hornině, jindy jsou uspořádané do ne zcela pravidelných paralelních šmouh. Pomocí práškové difrakční analýzy bylo zjištěno, že podíl chloritoidu je v hornině spíše akcesorický. Podle Rietveldovy analýzy difrakčních dat se jeho obsah $v$ hornině pohybuje kolem 3 až $5 \mathrm{hm}$. \%. Dominuje illit muskovitická fáze a křemen (oba minerály jsou přítomné v množství kolem $40 \mathrm{hm}$. \%). Dále byl zjištěn chlorit (ca 8 - 10 hm. \%), paragonitický slídový minerál (2 - 5 hm. \%), rutil (pod $2 \mathrm{hm}$. \%) a stopy kalcitu. V hornině nebyly vůbec zjištěny živce.

Přítomnost minerálu chloritoidové skupiny byla po-

Tabulka 1 Chemické složení chloritoidu (hm. \%) a přepočet koeficientů empirického vzorce na sumu šesti aniontů (kyslík + chlór + fluor). B.d.I. - pod detekčním limitem.

\begin{tabular}{lrrrrrrrr}
\hline & mean & 1 & 2 & 3 & 4 & 5 & 6 & 7 \\
\hline $\mathrm{FeO}$ & 23.98 & 23.49 & 23.18 & 24.86 & 24.18 & 24.19 & 23.50 & 24.50 \\
$\mathrm{MgO}$ & 2.68 & 2.72 & 3.08 & 2.47 & 2.46 & 2.53 & 2.81 & 2.68 \\
$\mathrm{MnO}$ & 0.38 & 0.40 & 0.34 & 0.46 & 0.37 & 0.34 & 0.36 & 0.38 \\
$\mathrm{CaO}$ & 0.01 & b.d.I. & b.d.I. & b.d.I. & b.d.I. & b.d.I. & b.d.I. & 0.05 \\
$\mathrm{Al}_{2} \mathrm{O}_{3}$ & 40.34 & 41.38 & 40.54 & 39.81 & 40.18 & 40.57 & 39.58 & 40.30 \\
$\mathrm{Cr}_{2} \mathrm{O}_{3}$ & 0.01 & b.d.I. & b.d.I. & b.d.I. & b.d.I. & b.d.I. & 0.04 & 0.05 \\
$\mathrm{SiO}_{2}$ & 24.46 & 25.00 & 24.71 & 24.25 & 24.25 & 24.76 & 24.18 & 24.07 \\
$\mathrm{TiO}_{2}$ & 0.01 & b.d.I. & b.d.I. & b.d.I. & b.d.l. & b.d.I. & 0.07 & b.d.I. \\
\hline$\Sigma$ & 91.87 & 92.98 & 91.85 & 91.85 & 91.44 & 92.38 & 90.54 & 92.03 \\
\hline $\mathrm{Fe}^{2+}$ & 0.832 & 0.801 & 0.800 & 0.868 & 0.844 & 0.834 & 0.827 & 0.852 \\
$\mathrm{Mg}^{2+}$ & 0.166 & 0.165 & 0.190 & 0.154 & 0.153 & 0.156 & 0.176 & 0.166 \\
$\mathrm{Mn}^{2+}$ & 0.013 & 0.014 & 0.012 & 0.016 & 0.013 & 0.012 & 0.013 & 0.013 \\
$\mathrm{Ca}^{2+}$ & 0.000 & 0.000 & 0.000 & 0.000 & 0.000 & 0.000 & 0.000 & 0.002 \\
\hline$\Sigma$ & 1.012 & 0.980 & 1.002 & 1.038 & 1.011 & 1.001 & 1.016 & 1.034 \\
\hline $\mathrm{Al}^{3+}$ & 1.972 & 1.988 & 1.972 & 1.959 & 1.977 & 1.971 & 1.962 & 1.975 \\
$\mathrm{Cr}^{3+}$ & 0.000 & 0.000 & 0.000 & 0.000 & 0.000 & 0.000 & 0.001 & 0.002 \\
\hline$\Sigma$ & 1.972 & 1.988 & 1.972 & 1.959 & 1.977 & 1.971 & 1.964 & 1.977 \\
\hline $\mathrm{Si}^{4+}$ & 1.015 & 1.019 & 1.020 & 1.012 & 1.012 & 1.021 & 1.017 & 1.001 \\
$\mathrm{Ti}^{4+}$ & 0.000 & 0.000 & 0.000 & 0.000 & 0.000 & 0.000 & 0.002 & 0.000 \\
\hline$\Sigma$ & 1.015 & 1.019 & 1.020 & 1.012 & 1.012 & 1.021 & 1.019 & 1.001 \\
\hline $\mathrm{O}^{2-}$ & 6.000 & 6.000 & 6.000 & 6.000 & 6.000 & 6.000 & 6.000 & 6.000 \\
\hline & & & & & & & &
\end{tabular}


tvrzena práškovou rentgenovou difrakční analýzou na magnetických koncentrátech, připravených z podrcené a namleté horniny. Chloritoid je paramagnetický s výraznou magnetickou anizotropií a magnetickou susceptibilitou $389.10^{-6}$ [SI] (Haerinck et al. 2013, 2015). Uvedená orientační hodnota magnetické susceptibility je sice dosti nízká, umožňuje ale při použití dostatečně silného magnetického pole alespoň částečné nabohacení koncentrátu chloritoidem.

Chloritoid patři k nesosilikátům, vyznačuje se vrstevnatou strukturou a polytypií (Hanscom 1980). Známy jsou triklinické a monoklinické polytypy, detailní systematika polytypů u tohoto minerálu nebyla ale zatím publikována. Při alternativním výpočtu mřižkových parametrů pomocí Rietveldovy metody s použitím různých vstupních strukturních modelů byla nejlepší shoda (nejnižší hodnota $R_{w p}$, resp. $R_{\text {Bragg }}$ ) dosažena při použití strukturních dat pro triklinický polytyp chloritoidu s prostorovou grupou $P-1$ (Koch-Müller et al. 2000). Mřižkové parametry studovaného chloritoidu jsou: $a=5.483(1), b=5.479(1)$, $c=9.1476(5) \AA, \alpha=83.452(10)^{\circ}, \beta=76.639(11)^{\circ}, \gamma=$ $59.993(15)^{\circ}\left(R_{\text {Bragg }}=1.614 \%\right)$. Na relativně vysokou chybu výpočtu mřížkových parametrů chloritoidu má vliv jak dosti nízký podíl minerálu (cca $22 \mathrm{hm}$. \%) ve směsi, tak i jeho tendence $\mathrm{k}$ přednostnímu uspořádání $v$ práškovém preparátu.

Výsledky WDS bodových mikroanalýz jsou uvedeny $v$ tab. 1. Podle zjištěného průměrného empirického vzorce $\left(\mathrm{Fe}_{0.83} \mathrm{Mg}_{0.17} \mathrm{Mn}_{0.01}\right)_{\Sigma 1.01} \mathrm{Al}_{1.97}\left(\mathrm{SiO}_{4}\right)_{\Sigma 1.02} \mathrm{O}_{0.92}(\mathrm{OH})_{2.00}$ jde $\mathrm{O}$ chloritoid s obsahem magnesiochloritoidové komponenty $17 \%$ a ottrélitové komponenty $1 \%$. Obsahy $\mathrm{Na}, \mathrm{K}, \mathrm{Sr}$, $\mathrm{Ba}, \mathrm{Zn}, \mathrm{Ni}, \mathrm{V}, \mathrm{Sc}, \mathrm{F}$ a Cl byly ve všech bodových analýzách pod mezí detekce použité metody.

Paragonitický slídový minerál byl pomocí elektronové mikroskopie a mikroanalýzy pozorován jen vzácně z důvodu jeho nenápadnosti a jeho těsného prorůstání s illit-muskovitem. Vytváří v muskovitových agregátech vrostlé lamely. Oba fylosilikáty nebyly blíže studovány.

Při studiu prírodních lomných ploch a nábrusủ břidlice byly zjištěny některé akcesorické minerály včetně takových, které dosud z lokality nebyly uváděny. Dosti hojné jsou mikroskopické agregáty $\mathrm{TiO}_{2}$ fáze (podle RTG difrakčních analýz se jedná o rutil) o velikosti do $40 \times 20 \mu \mathrm{m}$ (obr. 3a) a poměrně vzácné prizmatické krystaly zirkonu o

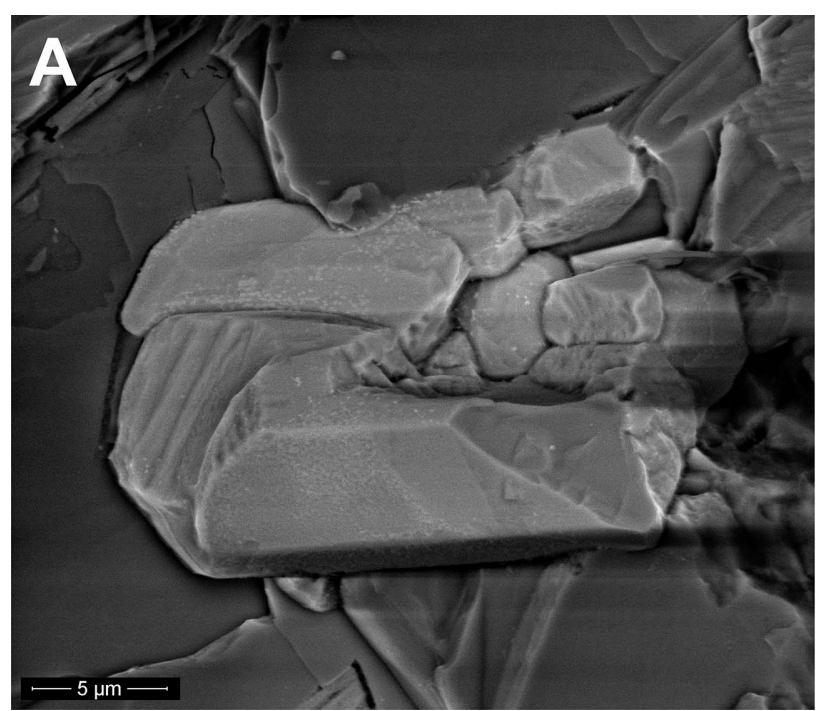

délce do $40 \mu \mathrm{m}$ (obr. 3b).

Specifickými akcesoriemi chloritoidové břidlice jsou pak xenotim-(Y) a rabdofán-(Ce). Xenotim-(Y) tvoří velmi vzácná izometrická zrna o velikosti do $10 \mu \mathrm{m}$ (obr. 4a). Ve zpětně odražených elektronech se jeví jako homogenní. Průměrný empirický vzorec, vypočtený na základě dvou bodových analýz je $\left(\mathrm{Y}_{0.71} \mathrm{Sm}_{0.01} \mathrm{Gd}_{0.03} \mathrm{~Tb}_{0}\right.$ $\left.{ }_{01} \mathrm{Dy}_{0.07} \mathrm{Ho}_{0.01} \mathrm{Er}_{0.05} \mathrm{Tm}_{0.01} \mathrm{Yb}_{0.04} \mathrm{Lu}_{0.01}\right)_{\Sigma 0.96}\left(\mathrm{P}_{1.02}^{.7} \mathrm{Si}_{0.01}\right)_{\Sigma 1.03} \mathrm{O}_{4.00}-$ tab. 2. Obsahy La, Ce, Al, As a S byly ve všech bodových analýzách pod mezí detekce použité metody. Xenotim akumuluje HREE s nejvyšším zastoupením Dy (5.6 hmot. $\% \mathrm{Dy}_{2} \mathrm{O}_{3}$ ). Obsahy La a Ce byly pod mezí detekce použité analytické metody. Obsahy U a Th jsou nízké - $0.5 \mathrm{hm}$. \% $\mathrm{UO}_{2}$ a $0.3 \% \mathrm{ThO}_{2}$ a vstupují do strukturní pozice A obecného vzorce minerálů rabdofánové skupiny $\mathrm{ABO}_{4} \cdot \mathrm{nH}_{2} \mathrm{O}$ substitucí $\mathrm{Ca}^{2+}+\mathrm{Th}^{4+} \leftrightarrow 2 \mathrm{REE}^{3+}$, respektive $\mathrm{Ca}^{2+}+\mathrm{U}^{4+} \leftrightarrow$ $2 \mathrm{REE}^{3+}$ (Ondrejka et al. 2018).

Rabdofán-(Ce) se ve studovaném metasedimentu vyskytuje $v$ podobě agregátů jehlicovitých krystalů, nacházejících se výhradně $v$ dutinách po dlouze sloupcovitém minerálu, patrně po apatitu (obr. $4 b$ ), které někdy téměř zcela vyplňuje (obr. 4c). Tyto krystaly dosahují maximální délky $25 \mu \mathrm{m}$ a tloušt'ky do $3 \mu \mathrm{m}$. Při vysokém zvětšení je patrné, že jehlicovité krystaly jsou kostrovitě vyvinuté, a prakticky všechny mají ve svých centrech otevřené dutiny (obr. 4d-f). Vnější omezení lépe omezených krystalků občas připomíná hexagonální prizmata, což je $v$ souladu se symetrií rabdofánu. Průměrný empirický vzorec, zjištěný na základě sedmi bodových analýz (tab. $2)$, je $\left(\mathrm{Y}_{0.01} \mathrm{La}_{0.18} \mathrm{Ce}_{0.40} \mathrm{Pr}_{0.04} \mathrm{Nd}_{0.15} \mathrm{Sm}_{0.03} \mathrm{Eu}_{0.01} \mathrm{Gd}_{0.04} \mathrm{Al}_{0.02} \mathrm{Ca}_{0 \text {. }}\right.$ $\left.{ }_{18} \mathrm{Fe}_{0.04} \mathrm{Th}_{0.02}\right)_{\Sigma 1.12}\left(\mathrm{P}_{0.95} \mathrm{Si}_{0.01} \mathrm{~S}_{0.01}\right)_{\Sigma 0.97} \mathrm{O}_{4.00} \cdot 0.97 \mathrm{H}_{2} \mathrm{O}$. Obsahy $\mathrm{Tb}, \mathrm{Ho}$, Er, Lu a Yb byly ve všech bodových analýzách pod mezí detekce použité metody. $V$ analýzách převládají LREE nad HREE, s Ce, La a Nd jako dominantními LREE kationty. Obsahy $Y$ se pohybují od 0.30 do $0.41 \mathrm{hm}$. \% $\mathrm{Y}_{2} \mathrm{O}_{3}$, respektive mezi 0.006 a 0.008 apfu Y. Významně zvýšený je obsah $\mathrm{Ca}$, který v průměru dosahuje $4.1 \mathrm{hm}$. $\% \mathrm{CaO}$, respektive 0.18 apfu Ca. Obsahy Zr, Yb, Sc a Lu byly pod mezí detekce použité analytické metody, obsahy As, U, Tb, Ho a Er nepřekročily 0.002 apfu. Vzhledem $\mathrm{k}$ velikosti krystalů a jejich kostrovému růstu nebylo možné zjistit jejich prípadnou chemickou zonálnost. Zajímavá je skutečnost, že PAAS normalizované distribuční křivky REE xenotimu a rabdofánu se vzájemně doplňuji (obr. 5).

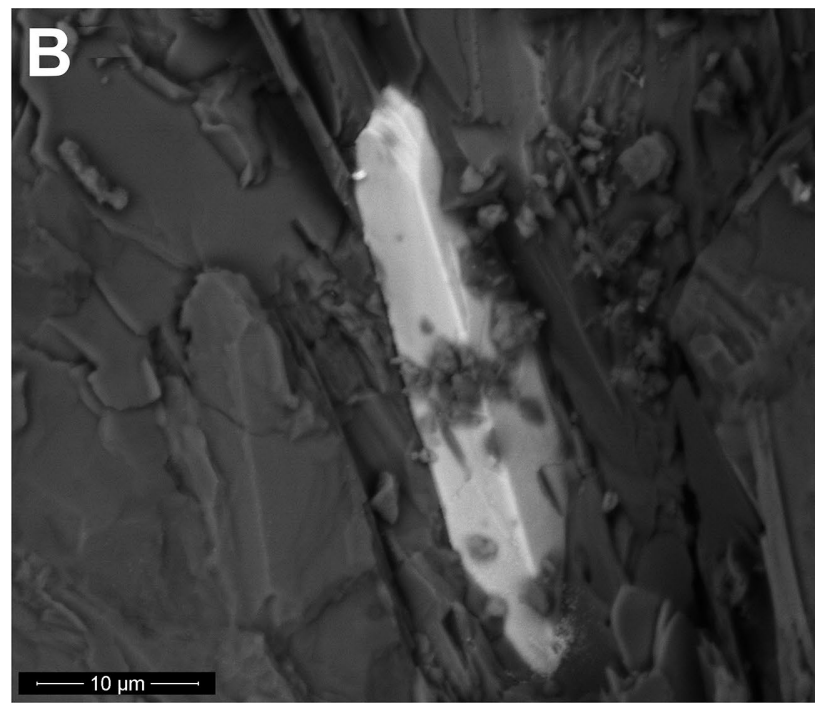

Obr. 3 Agregát rutilu $(A)$ a prizmatický krystal zirkonu (B) na lomné ploše horniny, zobrazené pomocí zpětně odražených elektronů. Foto $D$. Matýsek. 


\section{Závěr}

Minerál chloritoidové skupiny z kontaktně metamorfovaných ordovických sedimentů Železných hor, který byl po více než sto let $v$ literatuře uváděn jako ottrélit, je ve
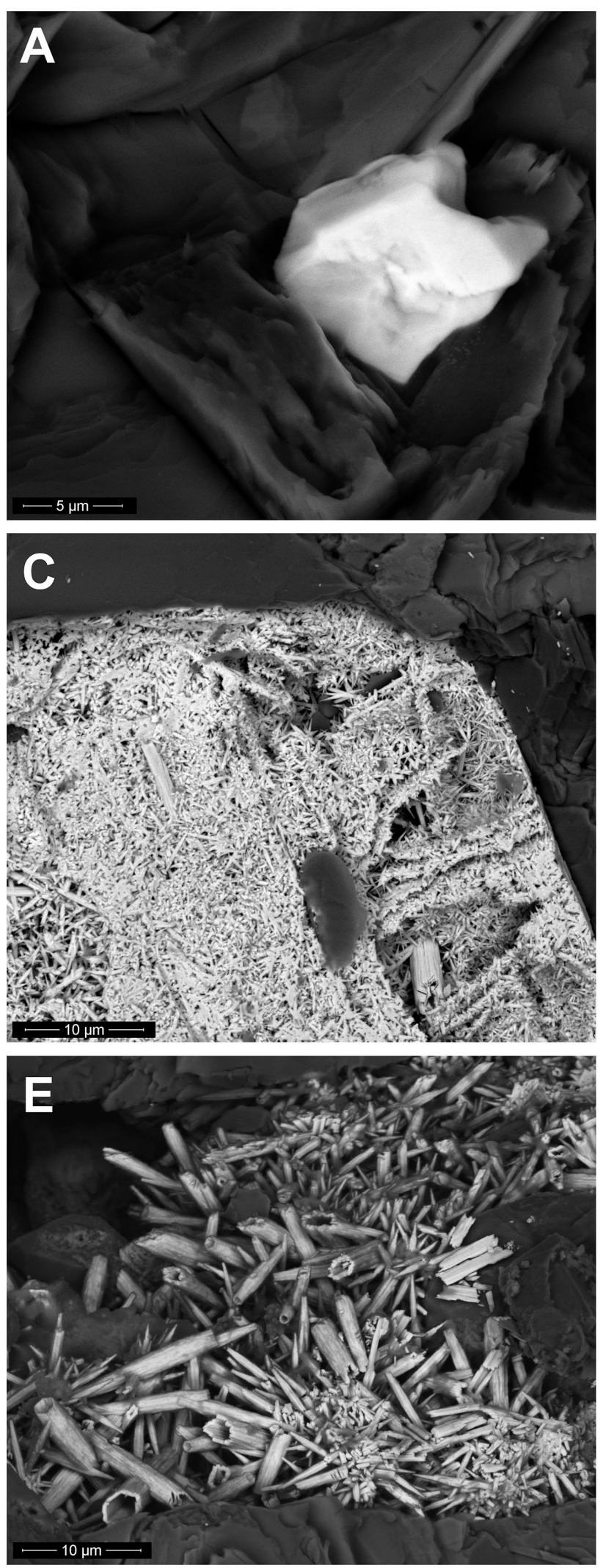

skutečnosti chloritoid s velmi nízkým obsahem ottrélitové komponenty $(1 \%)$. Pozoruhodné je, že celá situace by se dala označit jako „ztraceno v překladu“. Samotní autoři prvního zdejšího popisu toho minerálu, Krejčí a
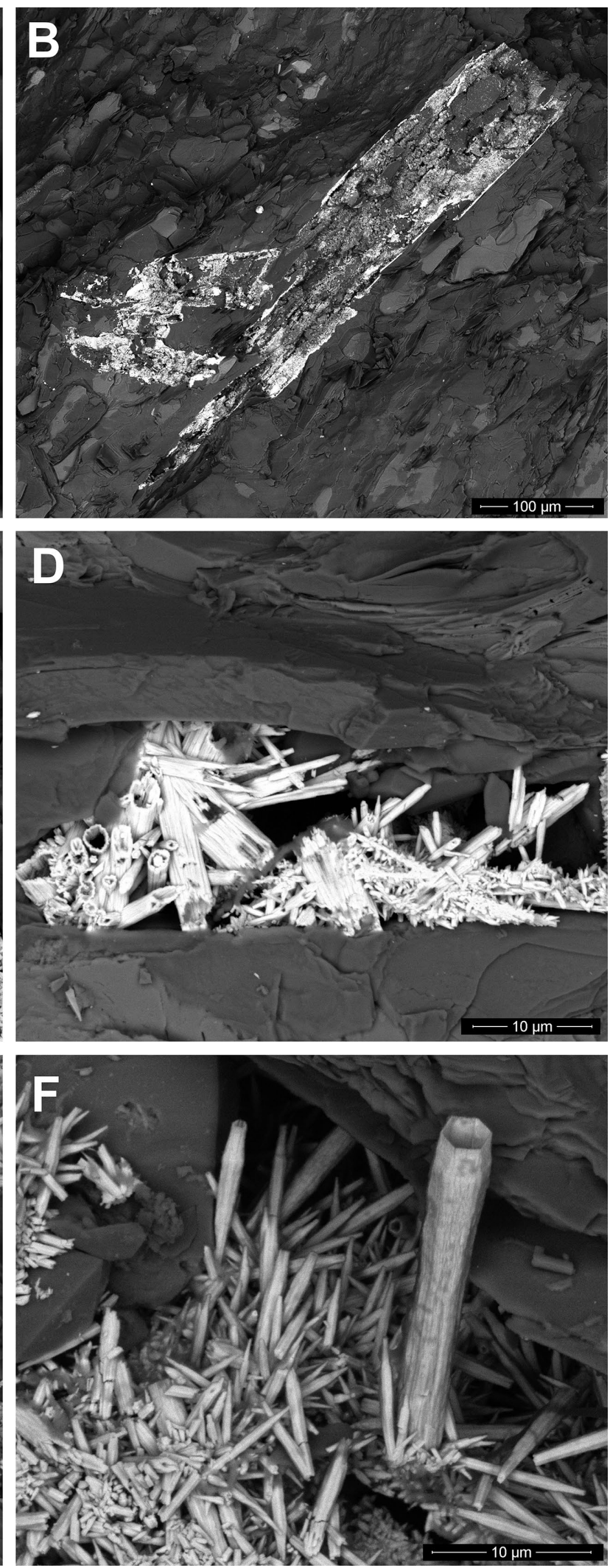

Obr. 4 Akcesorické minerály chloritoidové břidlice zobrazené pomocí zpětně odražených elektronů. $A$ - izometrické zrno xenotimu-(Y) na lomné ploše horniny. B-F - jehlicovité krystaly rabdofánu- $(C e)$, částečně vyplňující dutinu po pravděpodobném apatitu. Při velkém zvětšení je patrné, že velká část z nich představuje kostrovité krystaly. Foto D. Matýsek. 
Tabulka 2 Chemické složení xenotimu-(Y) a rabdofánu-(Ce) (hm. \%) a přepočet koeficientů jejich empirických vzorců na čtyři atomy kyslíku. Množství vody u rabdofánu bylo dopočteno na základě poměru strukturní pozice $\mathrm{B} / \mathrm{H}_{2} \mathrm{O}$ v ideálním vzorci. B.d.I. - pod detekčním limitem.

\begin{tabular}{|c|c|c|c|c|c|c|c|c|c|c|c|}
\hline & \multicolumn{3}{|c|}{ xenotim-(Y) } & \multicolumn{8}{|c|}{ rabdofán-(Ce) } \\
\hline & mean & 1 & 2 & mean & 1 & 2 & 3 & 4 & 5 & 6 & 7 \\
\hline $\mathrm{P}_{2} \mathrm{O}_{5}$ & 32.70 & 32.64 & 32.76 & 28.53 & 26.30 & 28.12 & 28.02 & 26.62 & 28.26 & 29.02 & 27.76 \\
\hline $\mathrm{As}_{2}^{2} \mathrm{O}_{5}$ & b.d.l. & b.d.l. & b.d.l. & 0.07 & 0.10 & 0.07 & 0.08 & 0.08 & 0.06 & 0.08 & 0.00 \\
\hline $\mathrm{SO}_{3}{ }^{\circ}$ & b.d.I. & b.d.I. & b.d.I. & 0.20 & 0.25 & 0.30 & 0.23 & 0.30 & 0.14 & 0.12 & 0.25 \\
\hline $\mathrm{SiO}_{2}{ }_{2}$ & 0.27 & 0.27 & 0.27 & 0.23 & 0.28 & 0.29 & 0.17 & 0.15 & 0.24 & 0.23 & 0.17 \\
\hline $\mathrm{ThO}_{2}$ & 0.26 & 0.25 & 0.26 & 2.05 & 0.82 & 3.46 & 2.79 & 0.68 & 3.83 & 0.42 & 3.08 \\
\hline $\mathrm{UO}_{2}{ }^{2}$ & 0.53 & 0.54 & 0.53 & 0.11 & 0.09 & 0.16 & 0.10 & 0.10 & 0.13 & 0.07 & 0.17 \\
\hline $\mathrm{Y}_{2} \mathrm{O}_{3}$ & 41.34 & 42.22 & 40.46 & 0.35 & 0.34 & 0.35 & 0.31 & 0.37 & 0.34 & 0.41 & 0.30 \\
\hline $\mathrm{La}_{2} \mathrm{O}_{3}$ & b.d.l. & b.d.l. & b.d.l. & 12.33 & 12.91 & 11.87 & 12.06 & 13.43 & 11.66 & 12.58 & 11.77 \\
\hline $\mathrm{Ce}_{2} \mathrm{O}_{3}^{3}$ & b.d.I. & b.d.I. & b.d.I. & 26.63 & 27.80 & 25.78 & 26.29 & 27.56 & 25.47 & 27.59 & 25.92 \\
\hline $\mathrm{Pr}_{2} \mathrm{O}_{3}$ & b.d.I. & b.d.I. & b.d.I. & 2.89 & 2.92 & 2.71 & 3.01 & 2.97 & 2.68 & 3.01 & 2.97 \\
\hline $\mathrm{Nd}_{2} \mathrm{O}_{3}$ & 0.30 & 0.36 & 0.23 & 9.99 & 10.52 & 9.21 & 9.92 & 10.36 & 9.55 & 10.10 & 10.27 \\
\hline $\mathrm{Sm}_{2} \mathrm{O}_{3}$ & 0.46 & 0.57 & 0.36 & 1.91 & 2.02 & 1.75 & 1.83 & 2.01 & 1.83 & 1.97 & 1.94 \\
\hline $\mathrm{Eu}_{2} \mathrm{O}_{3}$ & 0.09 & b.d.I. & 0.18 & 0.82 & 0.86 & 0.75 & 0.77 & 0.91 & 0.79 & 0.83 & 0.85 \\
\hline $\mathrm{Gd}_{2} \mathrm{O}_{3}$ & 2.13 & 2.15 & 2.10 & 2.98 & 3.14 & 2.84 & 2.95 & 3.09 & 2.84 & 3.11 & 2.91 \\
\hline $\mathrm{Tb}_{2} \mathrm{O}_{3}$ & 0.63 & 0.57 & 0.69 & b.d.I. & b.d.I. & b.d.I. & b.d.I. & b.d.I. & b.d.I. & b.d.I. & b.d.I. \\
\hline $\mathrm{Dy}_{2} \mathrm{O}_{3}$ & 5.55 & 5.31 & 5.80 & 0.15 & 0.13 & 0.14 & 0.14 & 0.19 & 0.14 & 0.17 & 0.16 \\
\hline $\mathrm{Ho}_{2} \mathrm{O}_{3}$ & 1.11 & 1.03 & 1.19 & b.d.I. & b.d.I. & b.d.I. & b.d.I. & b.d.I. & b.d.I. & b.d.I. & b.d.I. \\
\hline $\mathrm{Er}_{2} \mathrm{O}_{3}$ & 4.16 & 4.21 & 4.11 & b.d.I. & b.d.I. & b.d.I. & b.d.I. & b.d.I. & b.d.l. & b.d.I. & b.d.l. \\
\hline $\mathrm{Tm}_{2} \mathrm{O}_{3}$ & 0.67 & 0.67 & 0.67 & 0.14 & 0.21 & 0.16 & 0.18 & 0.22 & 0.18 & b.d.I. & b.d.I. \\
\hline $\mathrm{Yb}_{2} \mathrm{O}_{3}$ & 3.66 & 3.60 & 3.71 & b.d.I. & b.d.I. & b.d.I. & b.d.I. & b.d.I. & b.d.I. & b.d.I. & b.d.I. \\
\hline $\mathrm{Lu}_{2}^{2} \mathrm{O}_{3}$ & 0.70 & 0.69 & 0.72 & b.d.I. & b.d.I. & b.d.I. & b.d.l. & b.d.I. & b.d.I. & b.d.I. & b.d.I. \\
\hline $\mathrm{Al}_{2} \mathrm{O}_{3}$ & b.d.I. & b.d.I. & b.d.I. & 0.43 & 0.26 & 0.64 & 0.34 & 0.21 & 0.65 & 0.33 & 0.59 \\
\hline $\mathrm{Sc}_{2} \mathrm{O}_{3}$ & 0.02 & 0.01 & 0.02 & 0.03 & 0.05 & 0.02 & 0.02 & 0.02 & 0.03 & 0.03 & 0.05 \\
\hline $\mathrm{CaO}$ & 0.06 & 0.04 & 0.08 & 4.06 & 3.72 & 4.21 & 4.27 & 3.82 & 4.45 & 3.79 & 4.14 \\
\hline $\mathrm{FeO}$ & 0.14 & 0.09 & 0.19 & 1.15 & 0.85 & 1.18 & 1.42 & 0.86 & 1.10 & 1.13 & 1.51 \\
\hline $\mathrm{PbO}$ & 0.41 & 0.39 & 0.43 & 0.15 & 0.14 & 0.14 & 0.13 & 0.09 & 0.16 & 0.16 & 0.23 \\
\hline $\mathrm{H}_{2} \mathrm{O}^{*}$ & - & - & - & 3.62 & 3.77 & 3.49 & 3.67 & 3.67 & 3.48 & 3.68 & 3.55 \\
\hline$\Sigma$ & 95.26 & 95.71 & 94.80 & 97.98 & 99.70 & 95.81 & 98.79 & 99.10 & 96.37 & 98.06 & 97.99 \\
\hline $\mathrm{P}^{5+}$ & 1.017 & 1.012 & 1.022 & 0.950 & 0.962 & 0.932 & 0.957 & 0.957 & 0.938 & 0.966 & 0.941 \\
\hline $\mathrm{As}^{5+}$ & 0.000 & 0.000 & 0.000 & 0.001 & 0.002 & 0.001 & 0.002 & 0.002 & 0.001 & 0.002 & 0.000 \\
\hline $\mathrm{S}^{6+}$ & 0.000 & 0.000 & 0.000 & 0.007 & 0.008 & 0.009 & 0.007 & 0.009 & 0.004 & 0.004 & 0.008 \\
\hline $\mathrm{Si}^{4+}$ & 0.010 & 0.010 & 0.010 & 0.009 & 0.011 & 0.012 & 0.007 & 0.006 & 0.010 & 0.009 & 0.007 \\
\hline$\Sigma B$ & 1.027 & 1.023 & 1.032 & 0.968 & 0.983 & 0.955 & 0.973 & 0.973 & 0.954 & 0.981 & 0.956 \\
\hline $\mathrm{Y}^{3+}$ & 0.713 & 0.727 & 0.700 & 0.007 & 0.006 & 0.007 & 0.006 & 0.007 & 0.007 & 0.008 & 0.006 \\
\hline $\mathrm{La}^{3+}$ & 0.000 & 0.000 & 0.000 & 0.185 & 0.190 & 0.183 & 0.179 & 0.200 & 0.179 & 0.187 & 0.177 \\
\hline $\mathrm{Ce}^{3+}$ & 0.000 & 0.000 & 0.000 & 0.397 & 0.405 & 0.395 & 0.387 & 0.407 & 0.388 & 0.407 & 0.388 \\
\hline $\mathrm{Pr}^{3+}$ & 0.000 & 0.000 & 0.000 & 0.043 & 0.042 & 0.041 & 0.044 & 0.044 & 0.041 & 0.044 & 0.044 \\
\hline $\mathrm{Nd}^{3+}$ & 0.004 & 0.005 & 0.003 & 0.145 & 0.150 & 0.138 & 0.142 & 0.149 & 0.142 & 0.146 & 0.150 \\
\hline $\mathrm{Sm}^{3+}$ & 0.006 & 0.007 & 0.005 & 0.027 & 0.028 & 0.025 & 0.025 & 0.028 & 0.026 & 0.027 & 0.027 \\
\hline $\mathrm{Eu}^{3+}$ & 0.001 & 0.000 & 0.002 & 0.011 & 0.012 & 0.011 & 0.011 & 0.012 & 0.011 & 0.011 & 0.012 \\
\hline $\mathrm{Gd}^{3+}$ & 0.026 & 0.026 & 0.026 & 0.040 & 0.041 & 0.029 & 0.039 & 0.041 & 0.039 & 0.042 & 0.039 \\
\hline $\mathrm{Tb}^{3+}$ & 0.008 & 0.007 & 0.008 & 0.000 & 0.000 & 0.000 & 0.000 & 0.000 & 0.000 & 0.000 & 0.000 \\
\hline $\mathrm{Dy}^{3+}$ & 0.066 & 0.063 & 0.069 & 0.002 & 0.002 & 0.002 & 0.002 & 0.003 & 0.002 & 0.002 & 0.002 \\
\hline $\mathrm{Ho}^{3+}$ & 0.013 & 0.012 & 0.014 & 0.000 & 0.000 & 0.000 & 0.000 & 0.000 & 0.000 & 0.000 & 0.000 \\
\hline $\mathrm{Er}^{3+}$ & 0.048 & 0.048 & 0.047 & 0.000 & 0.000 & 0.000 & 0.000 & 0.000 & 0.000 & 0.000 & 0.000 \\
\hline $\mathrm{Tm}^{3+}$ & 0.008 & 0.008 & 0.008 & 0.002 & 0.003 & 0.002 & 0.002 & 0.003 & 0.002 & 0.000 & 0.000 \\
\hline $\mathrm{Yb}^{3+}$ & 0.041 & 0.040 & 0.042 & 0.000 & 0.000 & 0.000 & 0.000 & 0.000 & 0.000 & 0.000 & 0.000 \\
\hline $\mathrm{Lu}^{3+}$ & 0.008 & 0.008 & 0.008 & 0.000 & 0.000 & 0.000 & 0.000 & 0.000 & 0.000 & 0.000 & 0.000 \\
\hline $\mathrm{Al}^{3+}$ & 0.000 & 0.000 & 0.000 & 0.021 & 0.012 & 0.032 & 0.016 & 0.010 & 0.032 & 0.016 & 0.028 \\
\hline $\mathrm{Sc}^{3+}$ & 0.001 & 0.000 & 0.001 & 0.001 & 0.002 & 0.001 & 0.001 & 0.001 & 0.001 & 0.001 & 0.002 \\
\hline $\mathrm{Ca}^{2+}$ & 0.002 & 0.001 & 0.002 & 0.177 & 0.159 & 0.188 & 0.184 & 0.165 & 0.198 & 0.164 & 0.181 \\
\hline $\mathrm{Fe}^{2+}$ & 0.004 & 0.003 & 0.006 & 0.039 & 0.028 & 0.041 & 0.048 & 0.029 & 0.038 & 0.038 & 0.052 \\
\hline $\mathrm{Pb}^{2+}$ & 0.004 & 0.004 & 0.004 & 0.002 & 0.001 & 0.002 & 0.001 & 0.001 & 0.002 & 0.002 & 0.003 \\
\hline $\mathrm{Th}^{4+}$ & 0.002 & 0.002 & 0.002 & 0.020 & 0.007 & 0.033 & 0.025 & 0.006 & 0.036 & 0.004 & 0.029 \\
\hline$U^{4+}$ & 0.004 & 0.004 & 0.004 & 0.001 & 0.001 & 0.002 & 0.001 & 0.001 & 0.001 & 0.001 & 0.002 \\
\hline$\Sigma A$ & 0.959 & 0.966 & 0.952 & 1.120 & 1.090 & 1.142 & 1.114 & 1.106 & 1.146 & 1.101 & 1.143 \\
\hline O & 4.000 & 4.00 & 4.000 & 4.000 & 4.000 & 4.000 & 4.000 & 4.000 & 4.000 & 4.000 & 4.000 \\
\hline $\mathrm{H}_{2} \mathrm{O}$ & - & - & - & 0.968 & 0.983 & 0.955 & 0.973 & 0.973 & 0.954 & 0.981 & 0.956 \\
\hline
\end{tabular}


Obr. 5 Normalizované obsahy REE $v$ průměrném xenotimu-(Y) a rabdofánu-(Ce). Normalizace provedena na PAAS podle Pourmanda et al (2012). Obsahy Dy a Tm v rabdofánu-(Ce) byly položeny na nulu jejich naměřené hodnoty (tab. 2) byly těsně nad mezí detekce a považujeme je za artefakty měrení.

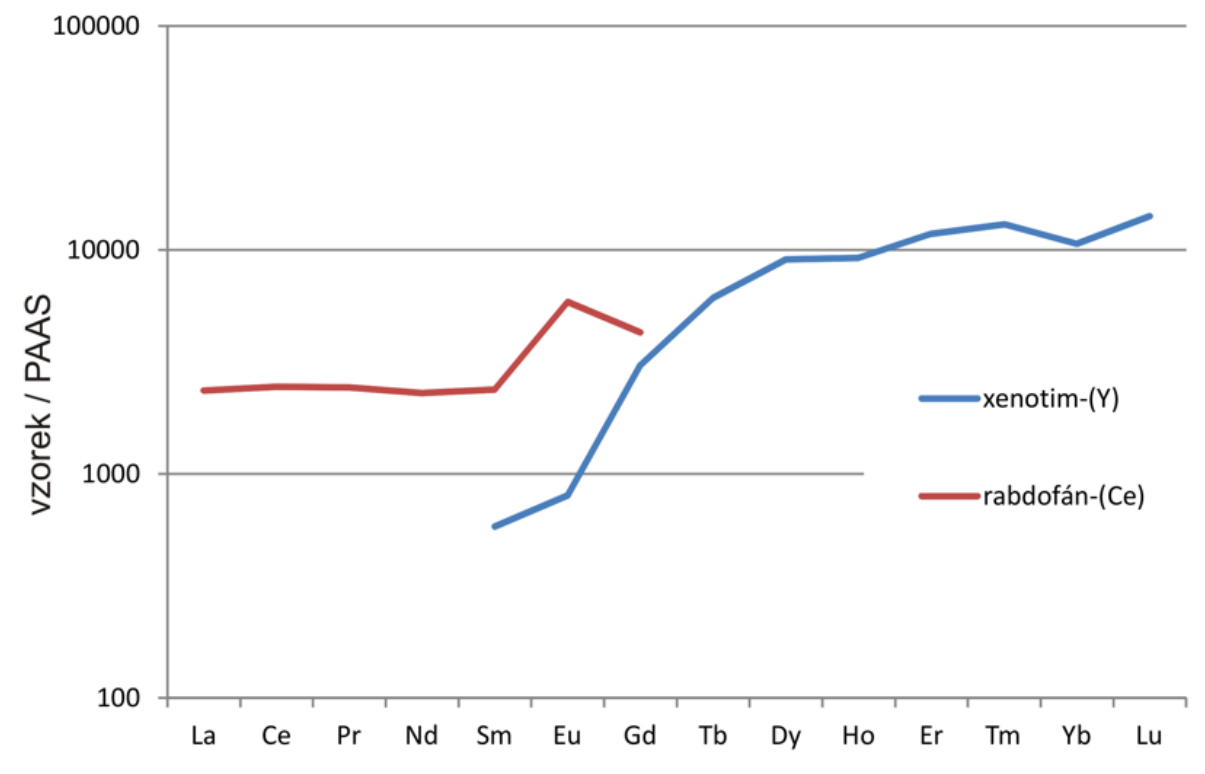

Helmhacker (1882), sice o minerálu píší jako o ottrélitu, ale vzápětí konstatují, že neobsahuje prakticky žádný mangan a neměl by se tak nazývat. Novější práce týkající se chemismu tohoto minerálu chybí, zato jeho původní označení v literatuře přetrvalo dodnes a detaily původní práce málokdo studoval.

Zajímavé jsou akcesorické minerály, které dosud ze zdejších „ottrélitových“ břidlic nebyly popsány. Jedná se o prizmatické krystaly zirkonu, drobná izometrická zrna xenotimu-(Y) a jehlicovitý rabdofán-(Ce). Poslední jmenovaný minerál se vyskytuje $v$ protáhlých dutinách, které pravděpodobně vznikly vyloužením pưvodního minerálu apatitové skupiny. Proto předpokládáme, že apatit byl zdrojem jak fosforu, tak REE potřebných pro vznik rabdofánu. Naopak xenotim, s ohledem na četnost, tvar, velikost a chemickou homogenitu, se jeví nejspíše primárním, respektive patří k původní asociaci těžkých minerálů. Xenotim ani rabdofán nejsou ve slabě metamorfovaných sedimentárních horninách pravděpodobně ani tak vzácné, jako spíše přehlížené. Autigenní vznik rabdofánu a xenotimu $v$ sedimentech karbonského stáŕí na našem území popisuji například Čopjaková a Škoda (2006, 2012). Rabdofán může z kyselých roztoků vznikat za teplot do $100{ }^{\circ} \mathrm{C}$ (Roncal-Herrero et al. 2011).

\section{Poděkování}

Děkujeme Mgr. Daliboru Velebilovi za pokus o dohledání Lázničkova údaje o chloritoidu z přednášek Národního muzea a Společnosti Národního muzea. Recenzentům Z. Lososovi a P. Paulišovi děkujeme za připomínky, které pomohly zvýšit kvalitu rukopisu.

\section{Literatura}

Burda J, Čurda J, Gürtlerová P, Holásek O, Klečák J, Knotek Z, Lysenko V, Majer V, Müller V, Rambousek P, TIMAA V, TOMÁšEK M (1993) Vysvětlivky k souboru geologických a ekologických účelových map prírodních zdrojů v měřítku 1: 50000 List 13-42 Pardubice. 1-46, Český geologický ústav Praha

ČopJAKOVÁ R, ŠKoda R (2006) Vznik autigenního xenotimu-(Y) v podmínkách velmi slabé metamorfózy drob a břidlic moravsko-slezského kulmu. Acta Mus Morav, Sci Geol 97: 55-69
ČopJAKová R, ŠKoda R (2012) Detritické a autigenní REE minerály v sedimentech kulmu Drahanské vrchoviny, jejich význam pro studium provenience klastického materiálu a procesů diagenese. Acta Mus Morav, Sci Geol 91: 105-127

Descloizeaux A, Damour AA (1842) De l'ottrélite. Nouvelle espèce minérale. Ann Mines 2: 357-361

FEDIUK F (1981) Minerály metamorfovaných hornin: Český masív. In Bernard JH (ed.) Mineralogie Československa, 2. vyd. 497-536. Academia Praha

FiedLeR KG (1832) Lagerstätten des Diaspor, Chloritspath, Pyrophyllit und Monazit, aufgefunden in Ural. Ann Phys Chem 25: 322-333

Haerinck T, Debacker TN, Sintubin M. (2013): Magnetic anisotropy of chloritoid. J Geophys Res-Sol Ea 118: 3886-3898

Haerinck T, Debacker TN, Sintubin M. (2015): Preferred mineral orientation of a chloritoid-bearing slate in relation to its magnetic fabric. J Struct Geol 71: 125-135

Hanscom R (1980) The structure of triclinic chloritoid and chloritoid polymorphism. Am Mineral 65: 534-539

HINTERLECHNER K, JOHN VC (1909) Über Eruptivgesteine aus dem Eisengebige in Böhmen. J K-Kön geol Reichsanst 59, 1: 127-244

HINTERLECHNER K, JOHN VC (1910) Über metamorphe Schiefer aus dem Eisengebige in Böhmen. Verh K-Kön geol Reichsanst 15: 337-353

Holásek O, Holásek O, Rambousek P, Tíma V (1989) Geologická mapa ČSR. List 13-42 Pardubice. Ústřední ústav geologický, Praha

HovORKA D (1969) Minerály metamorfovaných hornin: Český masív. In Bernard JH (ed.) Mineralogie Československa 320-332. Academia, Praha

CHOPIN C (1983) Magnesiochloritoid, a key-mineral for the petrogenesis of high-grade pelitic blueschists. Bull Mineral 106: 715-717

CHOPIN C, SCHREYER W (1983) Magnesio-carpholite and magnesiochloritoid: two index minerals of pelitic blueschists and their preliminary phase relations in the model system $\mathrm{MgO}-\mathrm{Al}_{2} \mathrm{O}_{3}-\mathrm{SiO}_{2}-\mathrm{H}_{2} \mathrm{O}$. Am J Sci 283A: 72-96

JoHAN Z, OUdIN E, PICOT P (1983) Analogues germanifères et gallifères des silicates et oxydes dans les gisements de zinc des Pyrénées centrales, France; argutite et carboirite, deux nouvelles espèces minérales. Tsch Mineral Petrogr Mitt 31: 97-119 
Koch-Müller M, Kahlenberg V, Schmidt C, WiRth R (2000) Location of $\mathrm{OH}$ groups and oxidation processes in triclinic chloritoid. Phys Chem Miner 27: 703-712

KRATOCHVIL J (1957) Topografická mineralogie Čech I: A-G. 1-855, Nakladatelství Československé akademie věd, Praha

KREJČí J, HeLmHACKER R (1882) Erläuterungen zur geologischen Karte des Eisengebirges (Železné hory) und der angrenzenden Gegenden im östlichen Böhmen. Arch naturwiss Landesdurchforsch Böhmen 5(1): $1-207$

Ondrejka M, Bačík P, Sobocký T, Uher P, ŠKoda R, Mikuš T, LUPTÁKOVÁ J, KONEČNÝ P (2018) Minerals of the rhabdophane group and the alunite supergroup in microgranite: products of low-temperature alteration in a highly acidic environment from the Velence Hills, Hungary. Mineral Mag 82(6): 1277-1300

PAULIŠ P (2003) Minerály České republiky: Kompletní přehled minerálů České republiky s uvedením jejich nejvýznamnějších lokalit. 1-120, Kuttna, Kutná Hora
Pourmand A, Dauphas N, Ireland TJ (2012) A novel extraction chromatography and MC-ICP-MS technique for rapid analysis of REE, Sc and Y: Revising Cl-chondrite and Post-Archean Australian Shale (PAAS) abundances. Chem Geol 291: 38-54

Roncal-Herrero T, Rodríguez-Blanco JD, Oelkers EH, BENNING LG (2011) The direct precipitation of rhabdophane $\left(\mathrm{REEPO} \cdot n \mathrm{H}_{2} \mathrm{O}\right)$ nano-rods from acidic aqueous solutions at $5-100{ }^{\circ} \mathrm{C}$. J Nanopart Res 13: 40494062

Rose G (1837) Mineralogisch-geognostische Reise nach dem Ural, dem Altai und dem Kaspischen Meere, Bd. 1. 1-641, Sanderschen Buchhandlung, Berlin

SLAVíkovÁ L (1939) Význačné přírůstky čs. sbírky nerostné v posledních pěti letech. Čas Nár Muz Odd přírodověd 113: 43-54

TUČEK K (1970) Naleziště českých nerostů a jejich literatura 1951-1965. 1-884, Academia, Praha

VEPŘEk P (ed) (1906) Chrudimsko a Nasavrcko: Díl I. Obraz přírodní. 1-137, Výbor ku popisu okresu Chrudimského a Nasavrckého, Chrudim 